\title{
Recent high-resolution mapping of Guaymas hydrothermal fields (Southern Trough)
}

\author{
Hélène Ondréas ${ }^{1, *}$, Carla Scalabrin ${ }^{1}$, Yves Fouquet ${ }^{1}$ and Anne Godfroy ${ }^{2}$ \\ 1 IFREMER, Géosciences Marines, CS 10070, Plouzané 29280, France \\ 2 IFREMER, CNRS, Université de Bretagne Occidentale, Laboratoire de Microbiologie des Environnements Extrêmes, UMR 6197, \\ CS 10070, Plouzané 29280, France
}

Received: 1 June 2017 / Accepted: 22 March 2018

\begin{abstract}
Insights into the factors controlling fluid circulation through the crust and the nature of fluid venting at the seafloor are first steps in understanding their effect on ocean properties and climate change. New data on the seafloor morphology, sub-surface sedimentary stratification, and water column of the sedimented Southern Trough hydrothermal field (Guaymas basin) were acquired during the BIG cruise in 2010. These data provide accurate and high-resolution information on the geological context of the vents, on the distribution of acoustic anomalies in the water column, and on the possible nature of the fluid generating these echoes. More than 40 hydrothermal edifices were observed. The southern zone of the study area hosts hydrothermal sites that differ from the northern area. The southern vents are located inside or at the edge of small sub-circular depressions and the relationship between active edifices and collapsed areas involves different steps in the continous hydrothermal setting. Sub-bottom data show surface and sub-surface events, with some reflection layers possibly indicating subsurface hydrothermal precipitates or lithification with an estimated age of approximately 10000 to 20000 years. Based on the position and maximum altitude of the acoustic anomalies above the seafloor, two types of fluid emission echoes are distinguished: 1) anomalies reaching a maximal altitude of $\sim 350 \mathrm{~m}$ above the seafloor and seen both at the northern and southern fields and 2) strong, narrow and straight anomalies reaching 1334 or $1702 \mathrm{~m}$ above the seafloor that are only present in the southern hydrothermal fields of the studied area. We suggest that there are two types of echoes reflecting different fluid escapes based on the physical conditions of fluid venting and degassing and their relationship to geologic features: hydrothermal fluids or hydrothermal fluid mixed with hydrocarbon gas, oil or condensates rising through the water column. The collapsed depressions observed in the southern part facilitate the release of light hydrocarbon (gas, oil, and condensates) soluble at a high temperature and transported by hydrothermal fluids towards the shallow sedimentary levels where they accumulate. These light hydrocarbons rapidly migrate at high levels in the water column. This contrasts with the northern fields where hydrothermal circulation linked to deeper faults, re-mobilize heavier non-soluble hydrocarbons which do not migrate at high levels in the water column.
\end{abstract}

Keywords: mid-ocean ridges / sedimented ridge / hydrothermal systems / fluid migration / water-column acoustic images / Guaymas basin

\begin{abstract}
Résumé - Cartographie haute résolution des champs hydrothermaux de la ride sud du bassin de Guaymas. La connaissance des facteurs contrôlant la migration des fluides dans la lithosphère et leur nature sur le fond de la mer est indispensable à la compréhension de leurs effets sur l'océan et le changement climatique. La campagne BIG, réalisée en 2010 sur le champ hydrothermal de la ride de Southern Trough (bassin de Guaymas), a permis l'acquisition de nouvelles données sur la morphologie des zones de sorties hydrothermales, la stratification de subsurface à proximité de ces zones et la nature des échos acoustiques enregistrés dans la colonne d'eau. Ces données nous permettent de préciser la nature du contexte géologique au niveau des sorties et, aidés de la répartition des échos dans la colonne d'eau, elles nous renseignent également sur la possible nature des fluides associés à ces sorties. Plus de 40 édifices hydrothermaux sont observés dans la zone d'étude montrant des différences morphologiques entre les sites localisés dans le nord et ceux présents dans le sud où ils se situent à l'intérieur ou en bordure de petites dépressions sub-circulaires
\end{abstract}

*Corresponding author: Helene.Ondreas@ifremer.fr 
bien marquées dans la morphologie. Les relations qui existent entre les édifices hydrothermaux et les structures effondrées semblent impliquer plusieurs stades de formation. Les données du sondeur de sédiment porté par l'AUV montrent des réflecteurs en subsurface, indiquant la présence de structures hydrothermales enfouies d'un âge de 10000 à 20000 ans, témoins des étapes de lithification hydrothermale. L'étude des anomalies acoustiques dans la colonne d'eau et de leur hauteur maximale au-dessus du fond révèlent deux types d'anomalies: des échos diffus ne dépassant pas une altitude de $350 \mathrm{~m}$ au-dessus du fond et, uniquement dans le sud, des échos étroits, plus marqués, atteignant 1334 et $1702 \mathrm{~m}$ au-dessus du fond. En regard des conditions physiques de stabilité des fluides et en lien avec les structures géologiques observées dans la zone, nous proposons que ces deux types d'échos représentent différents types de fluides : des fluides hydrothermaux, d'une part, et des fluides hydrothermaux mélangés à des hydrocarbures gazeux ou liquides dont des condensats, d'autre part. La présence des dépressions dans le sud de la zone peut agir sur la perméabilité et favoriser le relargage d'hydrocarbures légers présents en sub-surface qui vont remonter à travers la colonne d'eau. Au nord, la circulation hydrothermale en relation avec des failles plus profondes peut remobiliser des hydrocarbures plus lourds qui ne seront pas relargués dans la colonne d'eau.

Mots clés : dorsales / dorsales sédimentées / systèmes hydrothermaux / migration de fluides / images acoustique colonne d'eau / Bassin de Guaymas

\section{Introduction}

The geological setting of hydrothermal vents is increasingly studied at fine scales with high resolution tools (Wynn et al., 2014), bringing new insights into the factors controlling fluid migration into the lithosphere and discharge at the seafloor (Ondréas et al., 2012; Yoshikawa et al., 2012, Thal et al., 2014). High-resolution studies have been conducted at some vent fields (Clague et al., 2008, 2014; Jamieson et al., 2013), but few of them combine data on seafloor morphology, sub-surface sedimentary stratification and water column results for the same hydrothermal field.

Until recently, acoustic methods in marine geosciences have mostly been used to explore the seabed and to image subbottom units. Little attention has been given to the water column despite pioneer studies (Hay, 1984; Merewether et al., 1985; Palmer et al., 1986; Rona et al., 1991) and its extensive use in fisheries studies. Now, recent advances in technology and computer processing allow the execution of 3D acoustic surveys of the entire water column, revealing that fluid (liquids and gas) emissions from the seafloor are much more frequent than expected (e.g. Fleischer et al., 2001; Judd et al., 2002). The increasing number of systematic studies using water column acoustic data is helping us to better understand the distribution and nature of water column acoustic anomalies resulting from the discharge of fluids from natural seeps and vents according to different geological settings: continental margins (Römer et al., 2012) and their related features, such as pockmarks (Canet et al., 2010) and mud volcanoes (Sauter et al., 2006; Foucher et al., 2010; Canet et al., 2010), areas of active seismic faults (Dupré et al., 2015) and also, more recently, ridge environments (Nakamura et al., 2015).

Understanding the impact of fluids and degassing, especially carbon emissions (hydrocarbons, $\mathrm{CO} 2$ ), on ocean and atmosphere chemistry is a timely scientific topic. Recent studies in the Guaymas Basin (Berndt et al., 2016) emphasize the effect of magmatism in methane venting, which can in some situations directly reach the atmosphere, and likely contribute to global warming.

In the Guaymas Basin, Merewether et al. (1985) conducted a groundbreaking survey with a $23.5-\mathrm{kHz}$ inverted echo- sounder mounted on the Scripps Deep Tow vehicle in order to acoustically detect hydrocarbon plumes rising up through the water column. The plumes were detected outside of the area of known hydrothermalism, up to $2-\mathrm{km}$ above the seafloor in the southernmost zone of the Southern Trough (ST) and in the northeastern end of the Northern Trough (NT). The plume echoes were interpreted as having been produced by hydrocarbon-rich degassing.

No other water column acoustic survey has been carried out in the Guaymas Southern Trough since and the distribution of plumes according to the geological context remains a challenging issue to address.

In this paper, we use new data acquired by an AUV that surveyed close to the seafloor to conduct high-resolution mapping of the bathymetry, the backscatter, and the seismic of the highly sedimented hydrothermal area of the Guaymas Southern Trough to better understand the spatial and temporal evolution of fluid discharges. The distribution of fluid escapes was determined by analyzing the acoustic signals recorded in the water column throughout the study area with a shipborne multibeam echosounder. The acoustic anomalies detected from the ship were described in terms of morphology and volume into the water column, and used to infer the nature of the emitted fluids and how they can be related to geological patterns observed in this area of the Guaymas Southern Trough.

\section{Geological setting and previous work}

The Gulf of California hosts a zone of oblique extension that records the transition from seafloor spreading of new oceanic crust in the south to the rifting of the continental crust in the north (Fig. 1a and b) (Aragon-Arreola et al., 2005). In the Guaymas Basin, two overlapping fault troughs constitute an active axis (Fig. 1b). Very active hydrothermal fields occur in the ST within a rift valley 3 to $5 \mathrm{~km}$ wide and $30 \mathrm{~km}$-long (Fig. 1c and d).

Seafloor eruptions are inhibited by the rapid deposition of low-density sediments, and magmatic activity occurs as intrusions of shallow dikes and sills (Einsele et al., 1980). The sedimentary cover in the ST is up to $500 \mathrm{~m}$ thick. Drilling 
H. Ondréas et al:: BSGF 2018, 189, 6
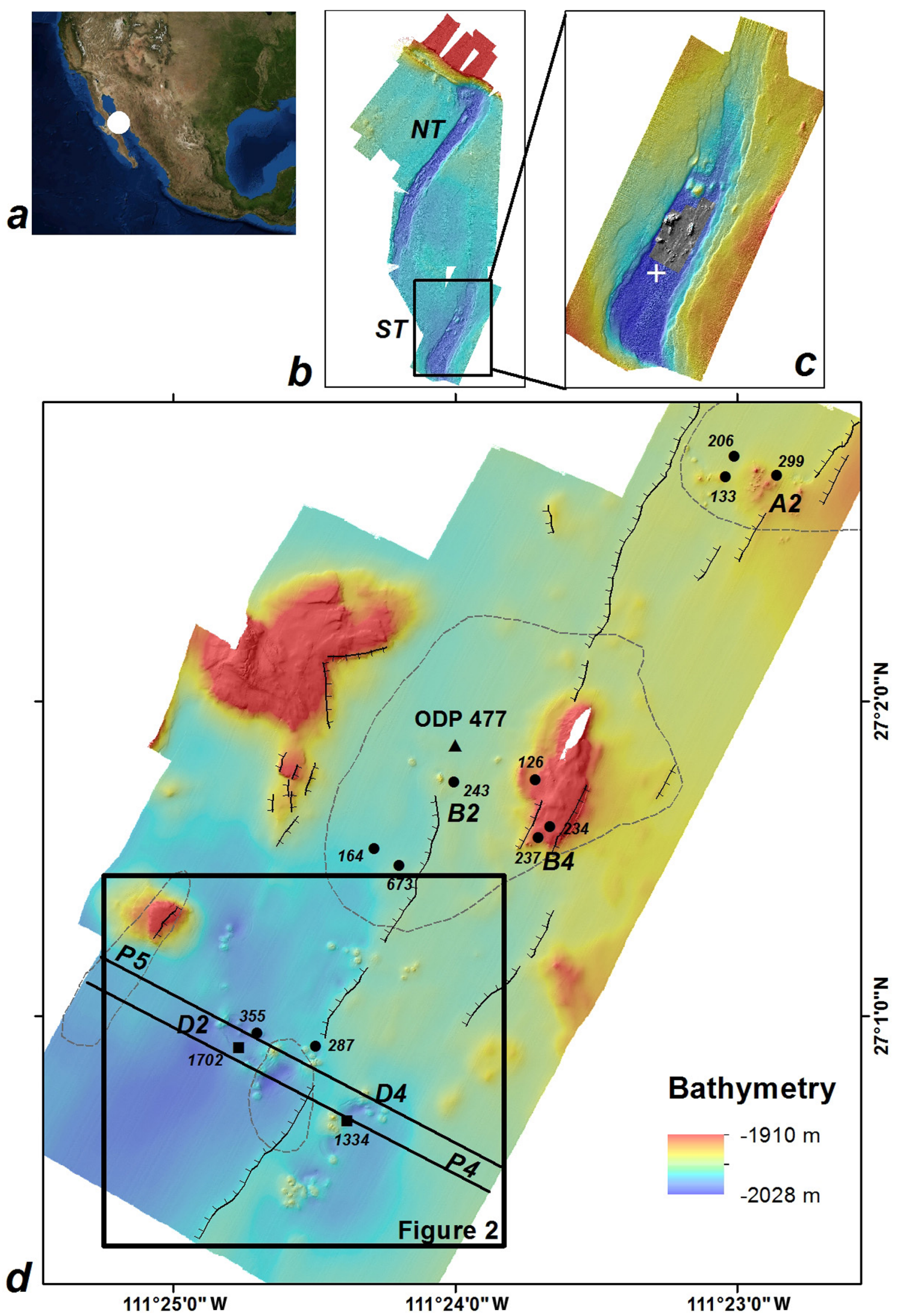

Page 3 of 15 
operations (DSDP site 477) penetrated late Quaternary, hemipelagic- and turbiditic facies sediment composed of muddy diatom oozes with high water content and mud turbidite units, (unit 1 - Curray et al., 1982) and hydrothermally altered and indurated mud turbidites (unit 2 - Curray et al., 1982). The two units are separated by tholeiitic and dolerite sills.

There have been numerous studies regarding hydrothermal processes in the Guaymas troughs. The first evidence for hydrothermal deposits in the Guaymas Basin was provided by Lonsdale et al. (1980). Since then, studies have been conducted on the nature of hydrothermal systems (Gieskes et al., 1982), their relationship to faulting (Lonsdale and Lawver, 1980; Lonsdale and Becker, 1985), the heat flow and the existence of a magma chamber in the ST (Lonsdale and Becker, 1985), the cyclical changes in the structure of the spreading axis (Kluesner et al., 2014), the magmatic intrusions and their thermogenic alteration of sediment (Lizarralde et al., 2010), and the high amount of methane venting due to rift magmatism (Berndt et al., 2016).

Many studies have focused on the formation and characteristics of Guaymas hydrothermal petroleum (Simoneit and Lonsdale, 1982; Simoneit, 1985; Kawka and Simoneit, 1987; Welhan and Lupton, 1987; Simoneit et al., 1988; Didyk and Simoneit, 1990; Peter et al., 1990, 1991; Marchand et al., 1994). Biological and microbiological experiments are also regularly conducted in the ST hydrothermal fields (Teske et al., 2002, 2016).

Merewether et al. (1985) detected hydrocarbon-rich plumes: $\sim 400 \mathrm{~m}$ above the seafloor in the south of the ST, $\sim 1000 \mathrm{~m}$ above the seafloor of the northeastern end of the NT, and several other plumes in the shear zone of the transform fault located north of the NT. In addition, large-scale gas seepage and fluid emissions were described on the edges of the active pull-apart basin in the northern Gulf of California (Canet et al., 2010). In the Guaymas NT, the link between magmatic intrusions into the organic-rich sediments, high methane concentrations, and the presence of biological communities has also been explored (Lizarralde et al., 2010; Berndt et al., 2016).

\section{Materials and methods}

The BIG cruise was carried out in the Guaymas Basin in 2010 (Fig. 1a) on board the French R/V L'Atalante. The main goal of the cruise was the in situ exploration of vents for microbial studies. However, during the first leg of the bathymetry and water column survey, data were acquired at a speed of 8 knots using the ship-borne EM122 $(12 \mathrm{kHz})$ multibeam echosounder (Fig. 1b). Fine-scale AUV surveys (bathymetry, backscatter, and sub-bottom profiles) were also carried out over the central area of the ST (Fig. 1c and d).

Water-column acoustic data were processed with Sonarscope/3DViewer software developed at IFREMER (Dupré et al., 2015). Fluid emission echoes were detected and located by visual inspection of ship-borne water-column polar echograms corresponding to the data of each ping and along-distance echograms associated to the track of the vessel. The most probable position on the seafloor and the maximum height (altitude above the seafloor) of each group of echoes attributed to rising fluids were determined (Fig. 1d).

The most accurate geographical position of the emission structure was assumed to be within a $50 \mathrm{~m}$ diameter circle corresponding to the acoustic beam footprint for water depths of $2000 \mathrm{~m}$, which approximately matches the scaled size of the points shown on Figure 1d. The reported acoustic height of a fluid emission corresponds to the upper limit of visible echoes as seen in the polar echogram. This upper limit cannot be straightforwardly associated to the true gas dissolution depth because bubbles can simply shrink or a bubble's volume can be reduced to the point of making it acoustically undetectable above a certain altitude, which is also the case for mixtures of turbulent hot fluid with surrounding cold seawater.

The near-seafloor AUV surveys were conducted $70 \mathrm{~m}$ above the seafloor in the central area of the ST. The first survey collected fine-scale high-resolution bathymetry and backscatter data (Fig. 1d) using the EM2000 multibeam echosounder $(200 \mathrm{kHz})$. AUV acoustic data were processed to provide $2 \mathrm{~m}$ grided data resolution mapping of the study area. The second AUV survey collected data with a $1800-6200 \mathrm{~Hz}$ sub-bottom profiler (vertical resolution of $25 \mathrm{~cm}$ and penetration of up to $50 \mathrm{~m}$ ) along two profiles of $3 \mathrm{~km}$ each.

Several dives with the manned submersible Nautile were carried out to study certain vents and sample their microbial communities. All the data were integrated in a GIS to provide an accurate and global picture of the hydrothermal area.

\section{High-resolution bathymetry}

The high-resolution mapping carried out over the ST focused on the central area of the trough where hydrothermal vents are present (Fig. 1c and d). The presence of various structures, previously described by Lonsdale and Becker (1985), was confirmed: the rift valley, rift fault scarps, and the intra-rift hills consisting of uplifted sedimentary rocks and numerous hydrothermal vents (isolated or organized in clusters).

The current results show (Figs. 1d and 2) the presence of more than 40 hydrothermal edifices. Each hydrothermal edifice was identified on the $2 \mathrm{~m}$ resolution map, with the largest hydrothermal structures appearing as mounds of up to $80 \mathrm{~m}$ in diameter and $20 \mathrm{~m}$ in height (Figs. 2 and 3).

In the southern zone of the study area, major hydrothermal sites are located inside or at the edge of small sub-circular depressions 100 to $250 \mathrm{~m}$ long, 60 to $150 \mathrm{~m}$ wide and 6 to $12 \mathrm{~m}$ deep with variable orientations (Fig. $2 \mathrm{a}$ and b). Curved scarps along the edges are well expressed, with visible steps of 1 to $2 \mathrm{~m}$ high for some of them. These features cut some of the

Fig. 1. a) Location of the Guaymas Basin. b) EM122 bathymetry of the Guaymas spreading axis; NT, Northern Trough; ST, Southern Trough. c) Composite bathymetry of the Southern Trough with EM122 data (in color) and AUV high-resolution mapping (in gray). The location of the nearest plume described in Merewether et al. (1985) is indicated by a white plus sign. d) High-resolution AUV mapping in the central part of the Southern Trough; black circles and numbers indicate the location and the fluid emission echoes, respectively. Letter-number codes refer to the hydrothermal sites described in Lonsdale and Becker (1985); dotted lines represent the limits of sills (Lonsdale and Becker, 1985) and black barb-lines are the main faults redrawn from Lonsdale and Becker (1985) and from high-resolution bathymetry. The black lines labeled P4 and P5 correspond to the AUV sub-bottom profiles over the hydrothermal area. 

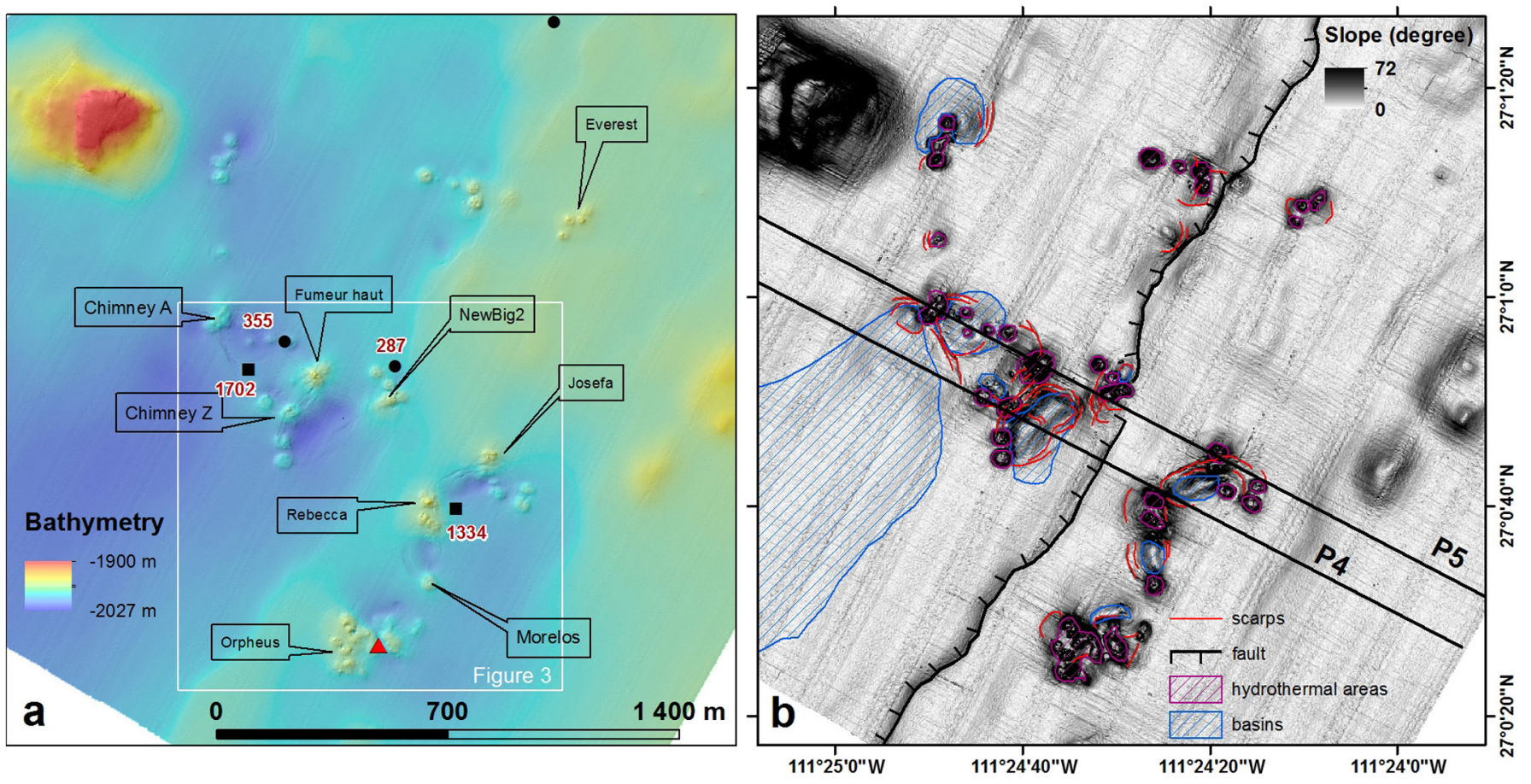

Fig. 2. a) Expanded high resolution bathymetry of the central part of the Southern Trough with location of fluid-emission acoustic images described in the text (black circles and squares) and their maximum altitude above the seafloor. The main vent sites are named. Red triangles indicate the point where oil discharges have been seen (see Fig. 6). b) Annotated structural interpretation of the same area shown in a) superimposed on an acoustic backscatter image. The black lines labeled P4 and P5 are the AUV sub-bottom profiles.

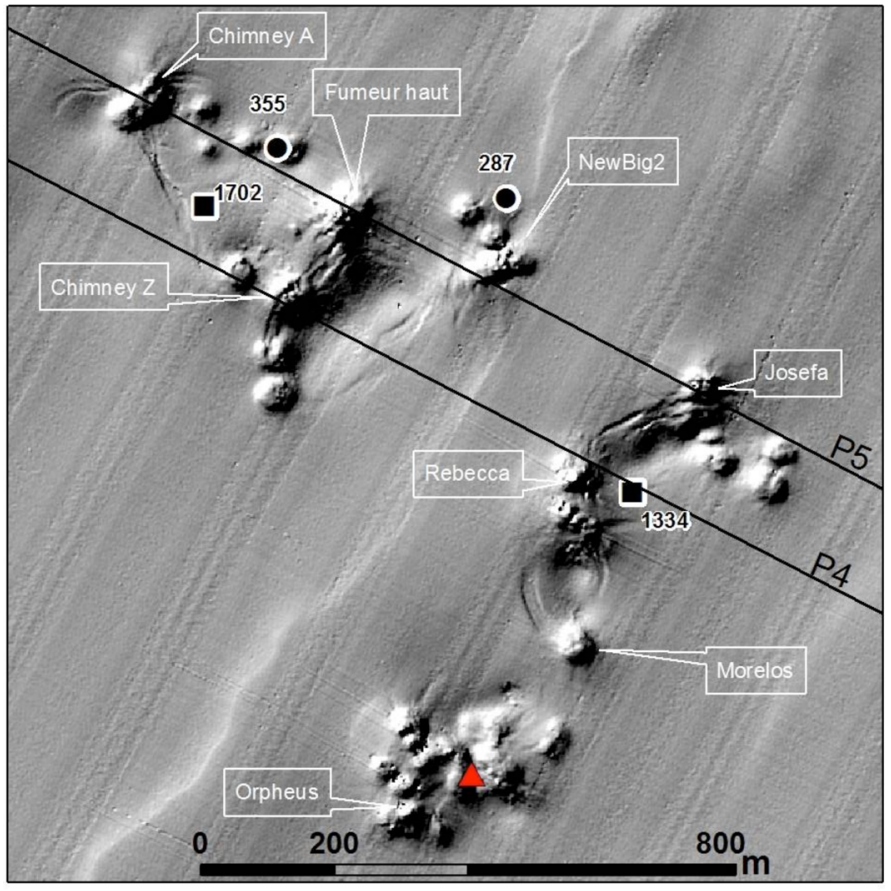

a)

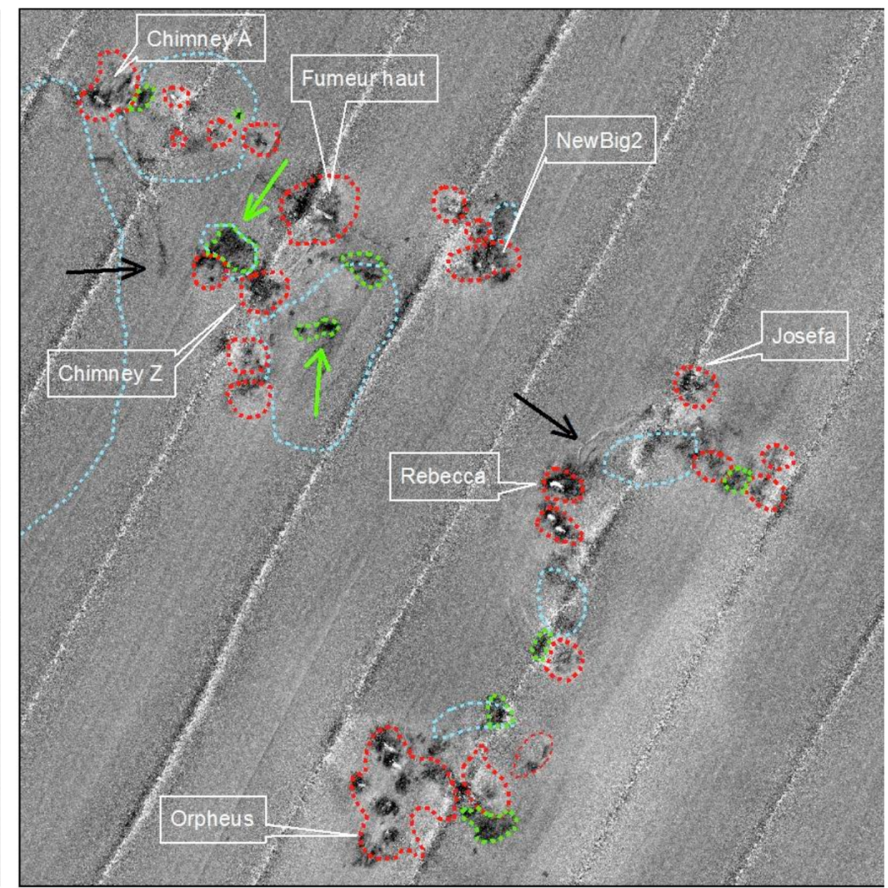

b)

Fig. 3. a) Shaded high-resolution bathymetric data focused on the southern hydrothermal area. Black circles and squares are the locations of fluid-emission echoes; red triangles indicate the locations of oil discharges (see text for explanations). b) High resolution backscatter data on the same area. High backscatter is shown as black areas and low backscatter as grey areas. Red dotted lines represent the extent of hydrothermal vents, blue dotted lines are the limits of basin structures, green dotted lines surround areas of strong backscatter out of hydrothermal vents. Black and green arrows emphasize some structures at the edges of basins (see text for explanations). 


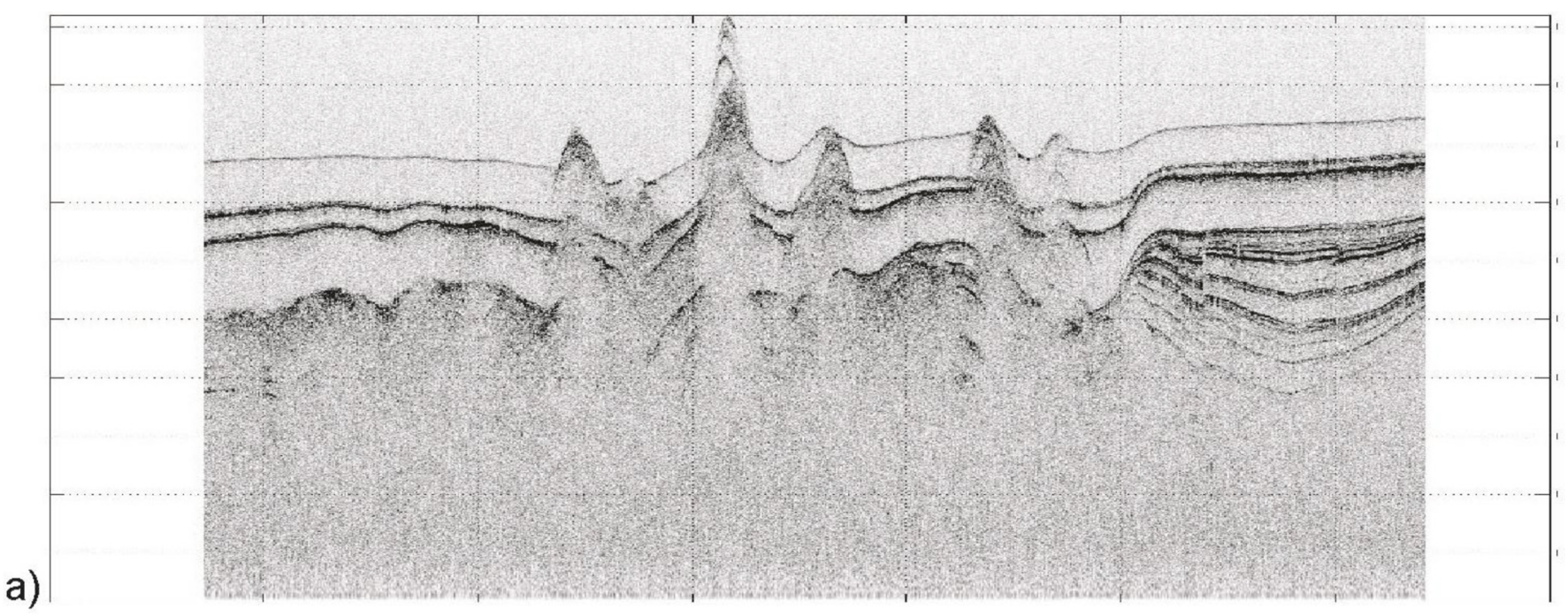

a)

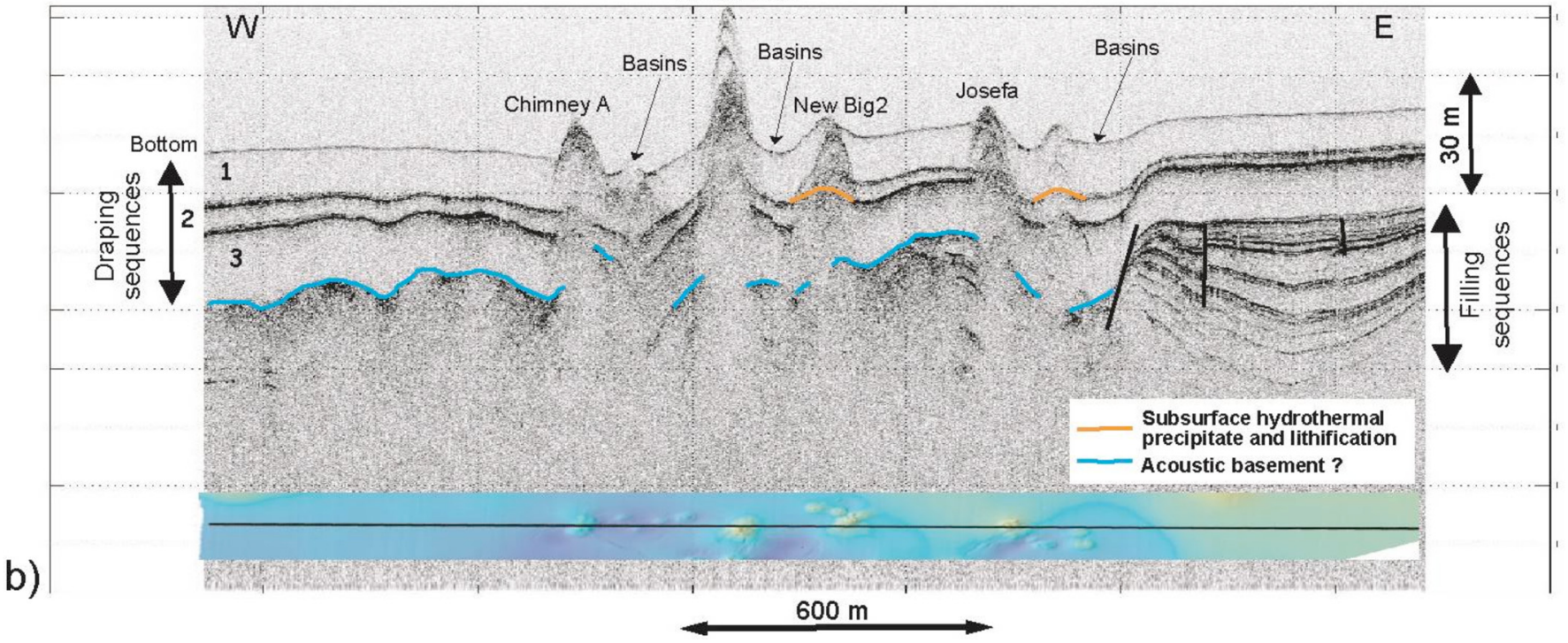

Fig. 4. a) Raw sub-bottom profile (line P5 on Fig. 3) over the active hydrothermal area. See Figures 1 and 2 for location. b) Interpreted sub-bottom profile P5 with the bathymetric map along the profile. c) Raw sub-bottom profile (line P4 on Fig. 3). See Figures 1 and 2 for location. d) Interpreted sub-bottom profile P4 with the bathymetric map along the profile. See text for explanations. Vertical exaggeration $=7$.

hydrothermal edifices, including Josefa and Chimney Z (Fig. 3a). Other hydrothermal edifices, such as Chimney A and Rebecca are not impacted by the possible slump scarps along depression edges. Smaller chimneys are located at the centre of some depressions. The main fault (Lonsdale and Becker, 1985), related to rifting and which cuts the area in it centre, is clearly visible on the high-resolution bathymetric maps (Figs. 2a and 3a).

On the high-resolution seafloor backscatter map (Fig. 3b), both low (in grey) and strong (in black) backscatter anomalies are present. Concerning strong reflectivity, we discern two types:

- anomalies linked to the presence of structures visible on the morphology (red dotted lines in Fig. 3b) such as hydrothermal vents or depression edges (see black arrows on Fig. 3b);

- anomalies not associated to structures visible in the morphology (green doted lines). This type of backscatter anomaly could be the expression of a superficial hard layer, such as recent hydrothermal deposits or sub-surface hydrothermal lithification due to lateral migration of fluids. It cannot reflect older hydrothermal deposits because these deposits, if buried by sufficient sediment, would not show a strong backscatter response. The depression areas present low backscatter values (grey zones in Fig. 3b) except on two areas near Chimney $Z$ (green arrows on Fig. 3b): the small basin located to the northwest and the focused area in the centre of the basin located southeast of the chimney. We propose that these areas represent recent hydrothermal implementation.

\section{Sub-bottom profiles}

The sub-bottom profiles (Fig. 4) show the filling and draping sequences related to the history of the ST basin. 
c)
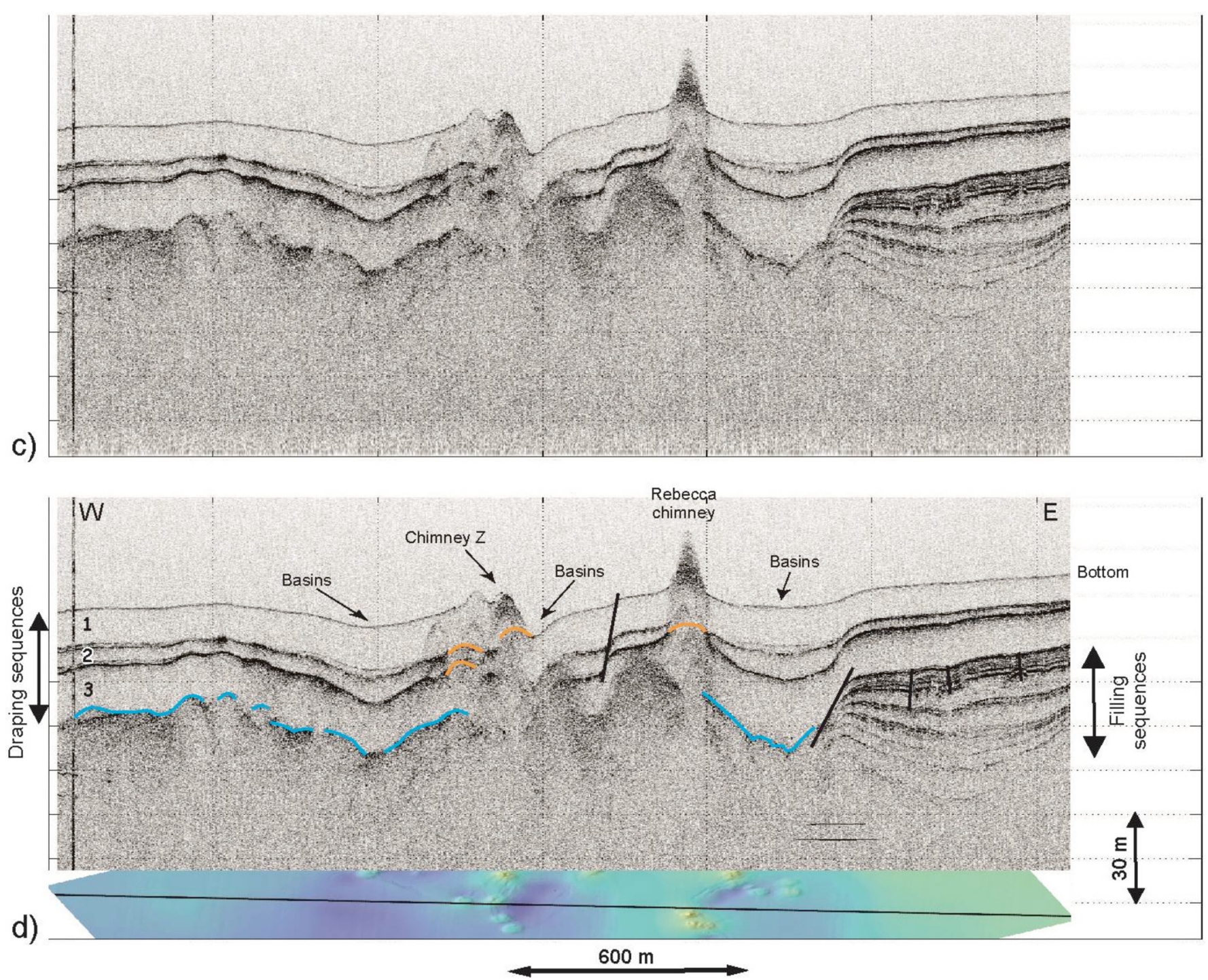

Fig. 4. (Continued)

Normal faults are buried in the sediment (Fig. 4a and b) or reach the surface like the main fault (Fig. 2b), as shown on profile 4 (Fig. $4 \mathrm{c}$ and d). The small depressions in the area of hydrothermal edifices are visible on sub-bottom profiles, however, it is not possible to observe the bordering curvedscarps, indicating that they are very superficial features. The small depressions overcome buried basins that seem to be structures inherited from the post-filling sequence. For some hydrothermal edifices, a "root" can be traced at least $40 \mathrm{~m}$ into the subsurface. These root structures are interpreted to represent fluid upflow pathways beneath the vents. Other hydrothermal chimneys show some buried reflections (orange lines on Fig. $4 b$ and d) that possibly indicate subsurface hydrothermal precipitates or lithification linked to hydrothermal mounds.

The sub-bottom profiles presented here penetrate $40-60 \mathrm{~m}$ when the bottom consists of the sediments of the filling sequences, but only $30 \mathrm{~m}$ in the area where a strong reflector noted as the "acoustic basement" is present. The results from ODP hole 477 (Gieskes et al., 1982) show the presence of coarse-grained dolerite sills at a depth of 50-60 m for hole 477 and a depth of $30 \mathrm{~m}$ below the seafloor for hole 477A. These basaltic intrusions were also confirmed by Lonsdale and Becker (1985) from side-sonar records (deep-tow near-bottom $4 \mathrm{kHz}$ ) and 3D seismic profiles. On the sub-bottom profiles (Fig. 4), the level noted as the "acoustic basement", from its seismic nature and depth below the seafloor could represent the top of an upper sill.

\section{Water-column acoustic anomalies}

In the study area covered by the AUV surveys, several water-column echoes of fluid emissions were detected with the 


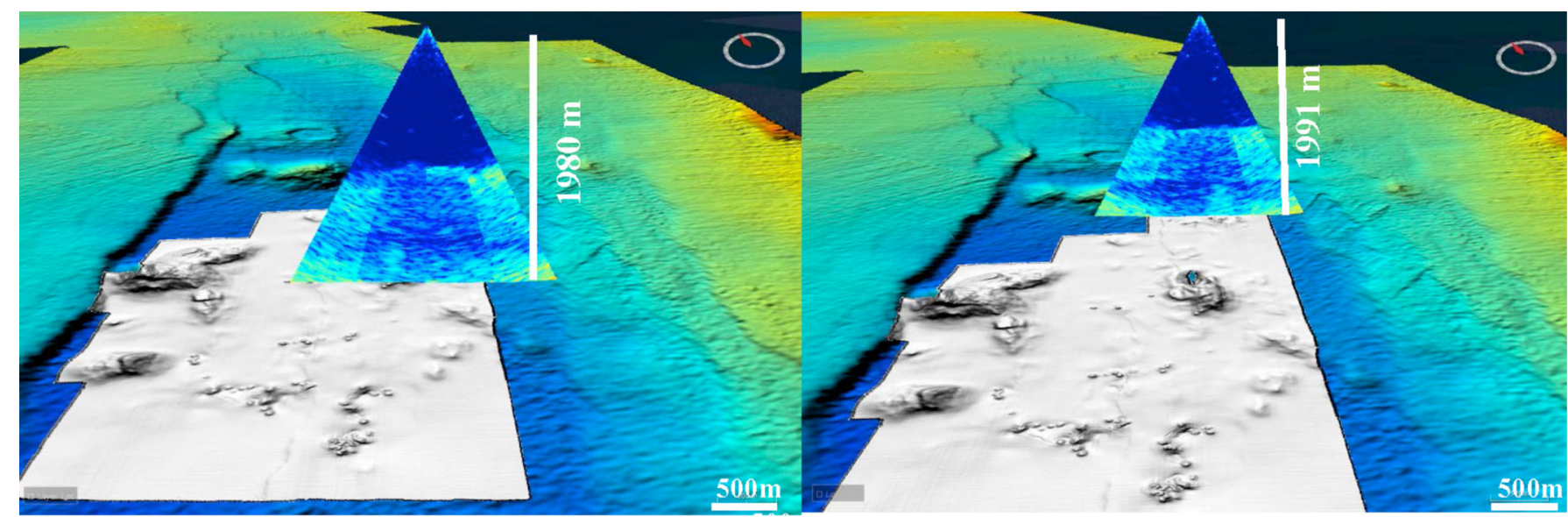

a) $32-75$-alt 237

b) $33-55$-alt 299

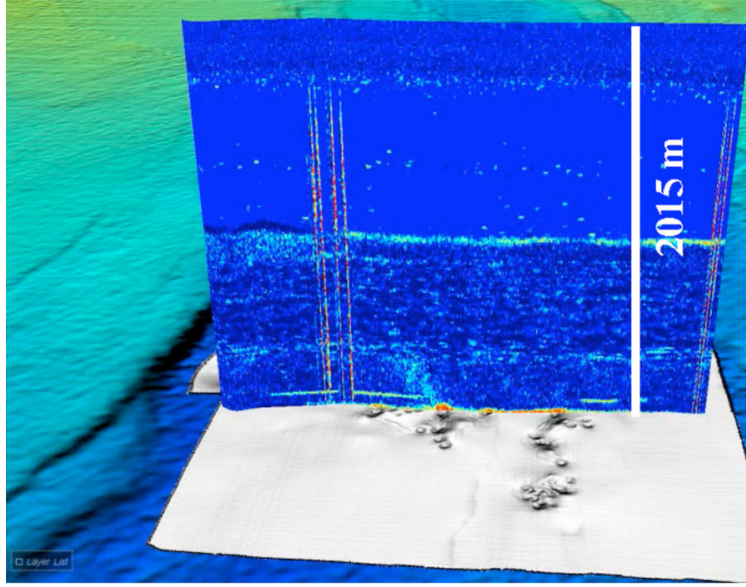

c) $24-44$-alt $355 \mathrm{~m}$

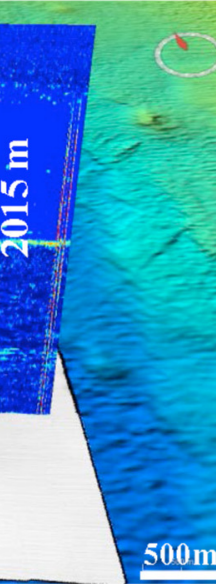

$500 \mathrm{~m}$

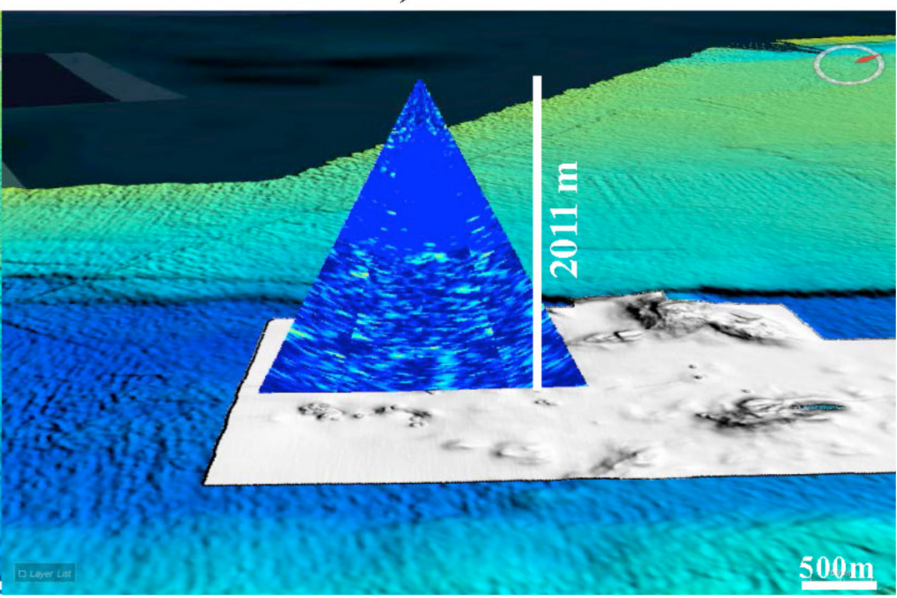

d) $24-226$-alt $\sim 287 \mathrm{~m}$

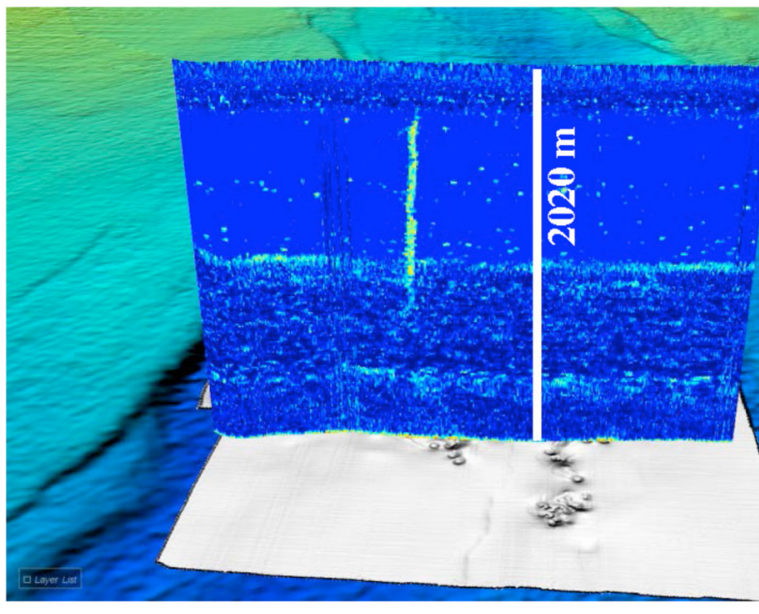

e) $24-49$-alt $1702 \mathrm{~m}$

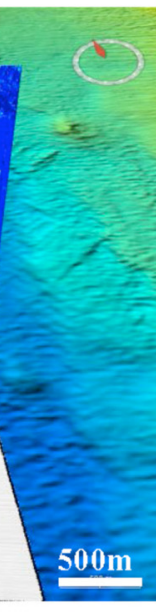

$500 \mathrm{~m}$

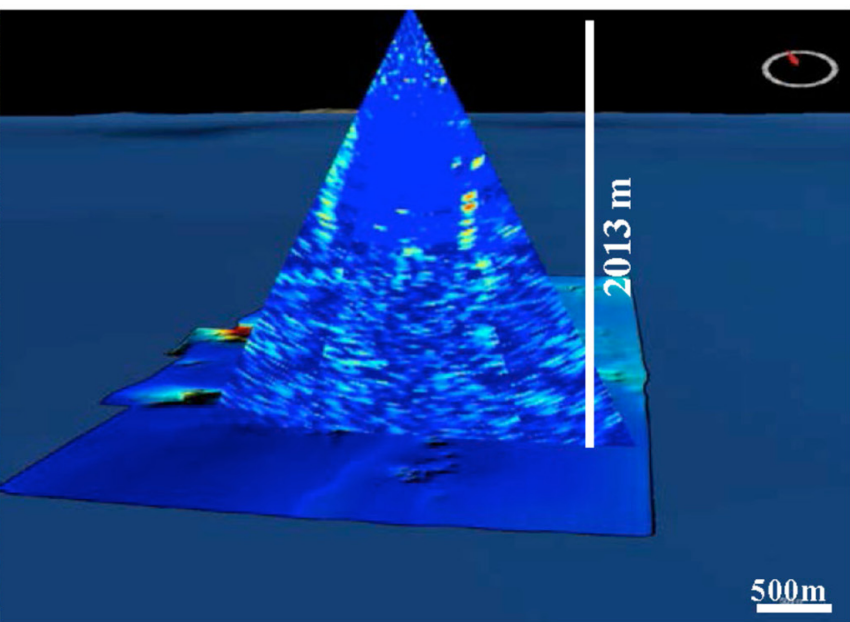

f) $15-290$-alt $1334 \mathrm{~m}$

Fig. 5. a) Polar echogram of plume " $237 \mathrm{~m}$ " (lighter blue echoes in the darker blue field) located in the central part of the mapped area. See Figure 1 for echo locations. b) Polar echogram of plume " 299 m" located in the northern part of the mapped area c) Along-track echogram of plume " $355 \mathrm{~m}$ " located in the southern part of the mapped area. d) Polar echogram of plume " $287 \mathrm{~m}$ " located in the southern part of the mapped area e) Along-track echogram of plume " $1702 \mathrm{~m}$ " located in the southern part of the mapped area. f) Polar echogram of plume " $1334 \mathrm{~m}$ " located in the southern part of the mapped area. 


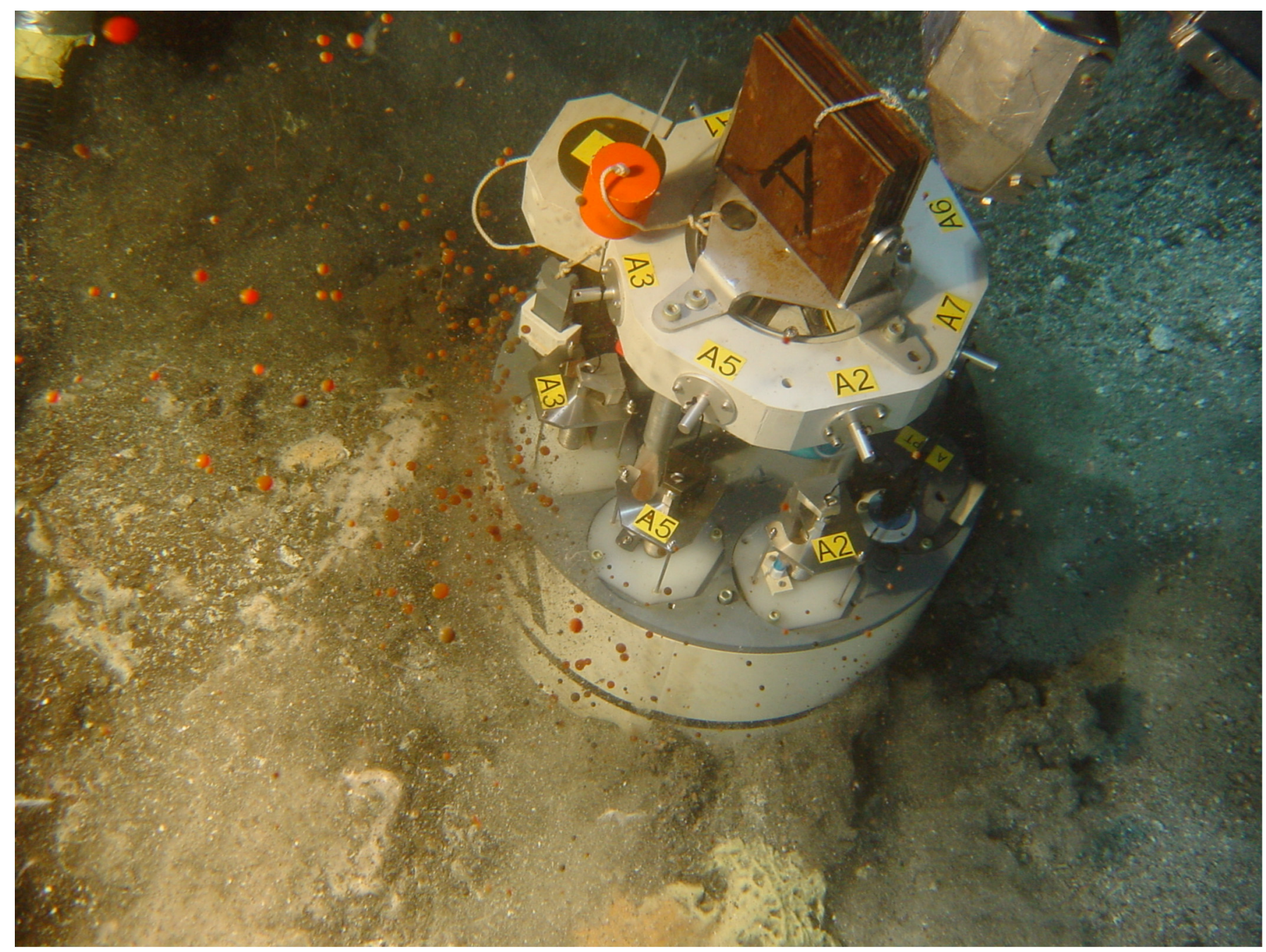

Fig. 6. Photo of oil discharges over hydrothermal chimney. The base of the benthic chamber is $40 \mathrm{~cm}$ in diameter. See Figure 2 for location (red triangle).

ship-borne multibeam echosounder EM122 during the BIG 2010 cruise (Figs. 1d and 2):

- in the northern zone, three fluid emission echoes with a maximum rise height of about $300 \mathrm{~m}$ (Fig. 5a and b) were observed near the A2 hydrothermal site described in Lonsdale and Becker (1985). This site hosts chimneys releasing fluid at $277^{\circ} \mathrm{C}$;

- in the central zone, several fluid emission echoes, with maximum rise height ranging between 126 and $673 \mathrm{~m}$, were observed near or between the hills consisting of uplifted sedimentary blocks (Lonsdale and Becker, 1985). Two of them (237 and $234 \mathrm{~m}$ high), located at the southern end of the East Hill, were near site B4 $\left(312^{\circ} \mathrm{C}\right)$. Another one was $126 \mathrm{~m}$ high and located along the fault scarp that defines the western edge of the East Hill. Between the two hills, the $243 \mathrm{~m}$ high fluid echo (Fig. 1) was located near the B2 hydrothermal site (Lonsdale and Becker, 1985) lying on a fault. Further south, there were two other fluid-emission acoustic signals that rose $164 \mathrm{~m}$ and $673 \mathrm{~m}$ high, respectively. They do not appear to be linked to any specific geological structure even if the $673 \mathrm{~m}$ high echo to the east is not far from a $040^{\circ}$ trending fault inside the trough. There is no reported hydrothermal vent near these two acoustic signals;

- in the southern zone, two fluid emission echoes, with a maximum rise height of 287 and $355 \mathrm{~m}$, were observed (Fig. 5c and d). Two other fluid-emission echoes (Fig. 5e and f), rising to 1702 and 1334 metres above the seafloor, are not far from hydrothermal chimneys. These echoes were observed southwest of the "Fumeur Haut" vent and close to the Rebecca site (Figs. 2 and 3). They are located in, or very close to, the small sub-circular depressions described previously (Figs. 1d, 2, and 3). The root of these acoustic anomalies on the seafloor are not visible but both extend continuously from $\sim 600 \mathrm{~m}$ above the seafloor up to a maximum rise height of 1702 and $1334 \mathrm{~m}$ with a vertical extent of $\sim 1100$ and $\sim 680 \mathrm{~m}$, respectively.

\section{Discussion}

\subsection{Surface and sub-surface hydrothermal events}

The bathymetric and backscatter data from the highresolution survey of the ST hydrothermal vent area (Fig. 3) 
enable us to provide an evolutionary sequence of surface and sub-surface hydrothermal events. Some chimneys are cut by superficial scarps at the edge of the small depressions, while other chimneys do not seem to be affected by the development of the depressions. We suggest a morphological evolution process including different evolutionary states of chimney development. A first generation of chimneys (e.g. Josefa, Chimney Z) is related to the early fluid pathways formed prior to the depression. They are then cut and partly collapsed along the circular slump scarps during the formation of the depressions.

Some chimneys along the edges of the collapsed subcircular depressions (e.g. Chimney A or Morelos in Fig. 3) are not affected by the slump scarps. They probably result from continuing venting after the collapse event. Due to changes in the fluid flow paths, they grow at locations different to the first generation of chimneys. These changes in pathways are probably due to a combination of hydrothermal alteration, subsurface hydrothermal precipitates and lithification of the sediments that modify permeability of the underlying sediment. The changes in fluids pathways may also be a consequence of the collapse event.

Small chimneys, located in the middle of some depressions (for example chimneys in the depression located between Chimney A and "Fumeur haut"), are materialized by strong echoes on the backscatter data (Fig. 3). The strong backscatter is due to subsurface lithification of the sediment, and the central chimneys may represent a late episode in development of individual vent structures.

The implementation of depressions, which are strongly controlled by the location of preexisting vents, is probably induced by hydrothermal dewatering, compaction and lithification by hydrothermal precipitates of the very young, soupy hemipelagic sediments. The compaction of underlying sediments may also trigger the slumps to impact some chimneys.

Permeability of surface interface influences the distribution of hydrothermal flow (Hearn et al., 2013) and restricts active fluid emission sites to the high-permeability zones. Around the depressions present on the southern part, localized hydrothermal lithification influences fluid pathways and increases fluid focusing along cracks. These cracks are generated by the collapse due to the compaction linked to hydrothermal diagenesis sustained in the lithified sediment. Furthermore, fluid discharge can contribute to deepening depressions by expelling unconsolidated superficial sediment (Pierre and Fouquet, 2007) out of the depression. The first generation of chimneys may play the role of a seal, limiting or inhibiting fluid circulation at the external edge of the depression possibly due to subsurface hydrothermal lithification of sediments, as observed in the Menez-Hom and Rainbow sites where rapid unexpected lithification of pelagic sediments is linked to low temperature diffuse circulation (Y. Fouquet, personal communication). The discharge can then move progressively towards the centre of the depression to settle chimneys, such as those appearing between "Chimney A" and "Fumeur haut".

On the sub-bottom profiles (Fig. 4), small sub-circular depressions have developed in the surface sediment of the basins. The seismic reflector noted as the acoustic basement is disrupted, and the upper blanking acoustic layer can be related to fluid perturbations located under vents. These seismic features show probable fluid migration pathways and potential interactions between fluids and the acoustic basement. We hypothesize that the layer named acoustic basement (30-40 m below the seafloor) could represent the top of the sill. The profiles presented here (Fig. 4) show vertical exaggeration equal to 7 but if reported with less or no vertical exaggeration, this reflector appears quite flat. Moreover, it is present on the western undisturbed part, out of the hydrothermal sediment lithification influence. Lonsdale and Becker (1985) discussed "shallow reverberant basement as possible sill" around only $30 \mathrm{~m}$ under the seafloor. On the ODP site, close to our studied area, Gieskes et al. (1982) report also the presence of sills at $30 \mathrm{~m}$ under the seafloor, which is the depth of our acoustic basement on the sub-bottom profiles.

The sedimentation rate of the Guaymas Basin is difficult to estimate, reports in literature vary between $0.3 \mathrm{~m} / \mathrm{ka}$ (Curray et al., 1982) and $2.7 \mathrm{~m} / \mathrm{ka}$ (Van Andel et al., 1964). Considering an average rate of $1 \mathrm{~m} / \mathrm{ka}$, as in Lizarralde et al. (2010), the base of the $30 \mathrm{~m}$ thick draping sequence (Fig. 4) could have an estimated age of 30000 years. Some reflectors, mapped under the present day chimneys (orange lines on Fig. 4) at $10 \mathrm{~m} \mathrm{bsf}$ (Fig. 4b) and $20 \mathrm{~m} \mathrm{bsf} \mathrm{(Fig.} \mathrm{4d)}$ respectively, which may represent subsurface hydrothermal precipitates and/or enhanced lithification of the sediments, are approximately 10000 to 20000 years old and indicate continuous hydrothermal discharges at this spot. In the hypothesis of continuous activity, the age of 20000 years is of the same order as hydrothermal activity on slow ridges. On the mid-Atlantic ridge, where most of the active hydrothermal sites are younger than 75000 years (Cherkashov et al., 2017), the TAG mound is 20000 years old (Lalou et al., 1993).

The mound structure discovered $\sim 1 \mathrm{~km}$ southeast of the northern rift axis of the Guaymas Basin must have formed during the last 5-10 k.y. (Berndt et al., 2016) thus being most recent. In the Middle Valley (ODP survey leg 169; Simoneit et al., 1992), the ${ }^{14} \mathrm{C}$ age of the bitumen from the chimneys was calculated to be about 30000 years BP. At this spot, buried superimposed mounds, with three stacked sequences of massive sulfides under the main mound, confirm successive episodes of hydrothermal discharges (Zierenberg et al., 1998).

\subsection{Inference on the nature of fluid emissions}

The nature of fluids escaping from the seafloor depends on the geology of the environment, the processes by which the fluids are generated, and the transformations in which they are involved during their migration from the sub-surface toward the seafloor, e.g.: hydrothermal fluids (clean or turbid, hot or cold), hydrocarbon gas (mainly methane), carbon dioxide, and oil droplets. Often their composition may result from the mixing of different fluids.

Although it is not feasible to obtain direct information on fluid composition from acoustic data, it is possible to draw some simple and reasonable inferences using the shape and intensity of echoes attributed to a fluid emission. Indeed, acoustic detectability, expressing the horizontal or vertical limit in distance for the detection of fluid emissions, depends on the composition (mainly the density and impedance contrasts between the fluid and the surrounding seawater), flow rate, and behaviour of the plume (Leblond et al., 2014). These factors can also define the shape and intensity of the echoes generated by the fluid emissions and thus provide indirect information on their nature. 
In the northern and central zones of the study area (except point "673"), where water depth varies between $1940 \mathrm{~m}$ to $2010 \mathrm{~m}$, fluid emissions rising through the water column were detected up to a maximun altitude of around $300 \mathrm{~m}$ above the seafloor and the corresponding acoustic images are composed of diffuse echoes (Fig. 5a and b).

Hydrothermal plumes generally have a physical limit to their vertical rise through the water column. Due to mixing and cooling of hot fluids with cold seawater, equilibrium in density is attained a few hundreds of metres above the seafloor, usually around $400 \mathrm{~m}$ (Speer and Rona, 1989). From modeling results, $\mathrm{Xu}$ et al. (2017) found that turbulenceinduced temperature fluctuations, rather than plume particles, are the dominant acoustic backscattering mechanism during the initial ten-metre rise of the plume. However, the relative contribution of plume particles to acoustic backscatter increases with height and may be significant at higher levels of the plume. Lavelle et al. (2013) acoustically imaged a hydrothermal plume up to $35 \mathrm{~m}$ from the seafloor in the Main Endeavour Field using COVIS facilities (Rona and Light, 2011) and provide model results showing a plume rising some $200 \mathrm{~m}$ above its source according to vertical velocity and density gradient estimates. The maximum rise height of a plume for constant stratification as a function of the horizontal cross flow was also computed from modeling by $\mathrm{Xu}$ and Di Iorio (2012). When the horizontal flow (currents) is weak or null, less ambient ocean water is dragged into the plume, the vertical velocity of the plume is larger, the temperature is hotter with increasing fluctuations and the estimated maximum rise height is $200 \mathrm{~m}$ ( $\mathrm{Xu}$ and Di Iorio, 2012). In the Guaymas Basin, Campbell and Gieskes (1984) demonstrated that hydrothermal venting in the Guaymas Basin can generate large clouds of fine suspended particulate matter above active mounds and chimneys up to a limit of $100-300 \mathrm{~m}$ above the seafloor. The presence of a physical limit for the upward migration of hydrothermal fluids, and the observations on the altitude of particulate dispersion in this area, support the idea that these echoes, observed only up to $300-350 \mathrm{~m}$ above the seafloor, are therefore generated by hydrothermal fluids.

In the southern zone of the study area, where the water depth varies from $1960 \mathrm{~m}$ to $2025 \mathrm{~m}$, two echoes reaching 355 and $287 \mathrm{~m}$ above seafloor were observed and seem consistent with the backscattering pattern of hydrothermal plumes (Fig. 5c and d). In contrast, two other strong and straight fluid echoes were observed up to an altitude of 1334 and $1700 \mathrm{~m}$ above the seafloor (Fig. 5e and f). Acoustic images of fluid emissions, located near the vent group called "Fumeur Haut", show echoes covering a height of $1100 \mathrm{~m}$ in the water column (between 600 and $1702 \mathrm{~m}$ in depth) while the other strong and straight echo stretchs overmore than $680 \mathrm{~m}$ (between 650 and $1334 \mathrm{~m}$ in depth). It seems unlikely that these echoes are generated by hydrothermal fluids. It rather appears that the observed echoes are the expression of strong density contrast with surrounding seawater and may have been generated by other targets, such as gas bubbles, hydrate/oil coated gas bubbles, liquid hydrocarbons condensates, or $\mathrm{CO} 2$. Different assumptions on the possible nature of the fluid generating strong and high echoes observed in the southern zone of the ST study area are discussed according to available information: dense liquid $\mathrm{CO} 2$ droplets, methane bubbles or methane-hydrate-coated bubbles, and hydrocarbon droplets or condensates.

Nakamura et al. (2015) observed similar acoustic anomalies rising vertically through the water column up to $\sim 1000 \mathrm{~m}$ from the seafloor above hydrothermal vents in the Okinawa Trough. They assumed that these anomalies could not be directly caused by the flow of hydrothermal vent fluid, but rather by the water mass associated with dense liquid $\mathrm{CO} 2$ droplets coated with a clathrate crust. In the Okinawa Trough this assumption is supported by the spatial relationship observed between the immersion location of the top of acoustic anomalies where echoes disappear and the carbon dioxide phase transition layer from liquid/clathrate to vapor. In the southern zone of the ST studied area, the echoes are not rooted at the bottom as most of those described in Nakamura et al. (2015) and the measured values of $\mathrm{CO} 2$ found in the interstitial gas of subsurface sediments of the ST (Hole 477, Galimov and Simoneit, 1982) are significantly lower than those observed in the Okinawa Trough (Sakai et al., 1990; Kawagucci et al., 2013). It is highly unlikely that the observed echoes in the southern zone of the study area could be generated by the expulsion of dense liquid $\mathrm{CO} 2$ droplets in the water column.

Plumes can also be composed of free-gas or gas-hydratecoated bubbles that rise up through the water column (Rehder et al., 2009). Methane plumes released in the Håkon Mosby mud volcano have been acoustically detected up to altitudes of more than $700 \mathrm{~m}$ (Sauter et al., 2006; Foucher et al., 2010). Greinert et al. (2006) identified bubbles from Black Sea mud volcanoes, reaching $1300 \mathrm{~m}$ high. In the Black Sea, Nikolovska et al. (2008) observed echoes from gas bubbles leaving cold seeps rise up to $540 \mathrm{~m}$ above the seafloor. They explain this upper limit assuming that bubbles become invisible at around $320 \mathrm{~m}$ from the sea surface due to the decrease in the volume ratio of gas and water or to shrinking as a result of gas dissolution that occurs as bubbles rise through the water column. Fluid echoes observed during the BIG2010 cruise in the southern zone of the study area could have been generated by methane bubbles or gas-hydrate-coated bubbles.

Indeed, it has been proposed that magma intruding into organic-rich sediment alters the sediments and releases carbon (Lizarralde et al., 2010; Berndt et al., 2016), creating thermogenic methane driven by heat from magmatic intrusions (Svensen et al., 2003). In the ST, the broad zone of shallow magmatic emplacement provides conditions for the release of a large volume of carbon from sediments through thermogenic alteration. The Guaymas hydrothermal fluids are carbon-rich (Von Damm et al., 1985) and in high-temperature hydrothermal fluids, light hydrocarbon gases (methane through pentane) are predominant and derived from the thermocatalysis of organic carbon in sediment intruded by mid-ocean ridge volcanic rocks (Welhan and Lupton, 1987). Methane seepage could then generate acoustic backscattering, however, the observation of rootless acoustic anomalies may not support this assumption. If the fluid expelled is constituted of gas, such as methane bubbles, then density contrast with seawater should be observed when fluid starts to ascend into the water column which is not the case.

The generation of such strong, high echoes above the seafloor can be caused by plumes composed of oil-coated bubbles or oil droplets and condensates released from natural marine seeps as, for example, in the Gulf of Mexico 
(MacDonald et al., 2002; Solomon et al., 2009). Here, oily bubbles, as opposed to non-oily bubbles, produce clear signatures extending from the seafloor to the near-surface on acoustic profiles (De Beukelaer et al., 2003).

The oil coating on bubbles probably limits the rate of bubble dissolution and increases their lifespan. The absence of dilution maintains the contrast in density, and plumes can rise higher in the water column. Heavier thermogenic hydrocarbons forming emulsions at some hydrothermal vents (Simoneit, 1982) have been interpreted as probably occurring at least as minor contaminants in some plumes detected in the south of the ST (Merewether et al., 1985). Typical condensate hydrocarbon distributions (C1-C10) are also described in the Guaymas vent fluids (Simoneit et al., 1988).

Visual inspections of the seafloor carried out by the Nautile submersible during legs 2 and 3 of the BIG cruise showed oil droplets of $\sim 0.5 \mathrm{~cm}$ to $1 \mathrm{~cm}$ in diameter expulsed in the area of hydrothermal vents (Fig. 6). No echoes have been shown here, as this is sometimes a sporadic phenomenon. A benthic chamber device, left several days on the bottom close to the Morelos vent (Fig. 2), was recovered with oil patches coating the instrument. Some chimney samples were stained with oil, and retained a persisting oil smell.

As in the case of gas bubbles described before, the two strong and narrow rootless echoes observed in the south are probably not oil-coated bubbles or oil droplets. However, they could reflect discharges of light hydrocarbon condensates which are directly converted from liquid to gas at a depth of $1350-1400 \mathrm{~m}$, as revealed by their occurence on acoustic images.

\subsection{Geological constraints on hydrocarbon and hydrothermal fluid discharges}

The two types of acoustic anomalies encountered in the water column are linked to different morphological features and depth differences between the southern and northern fields (Figs. 1d and 2). The northern area, where water depth varies between $1940 \mathrm{~m}$ to $2010 \mathrm{~m}$, has hydrothermal vents that are probably fault-controlled. Lonsdale and Becker (1985) show that " $\mathrm{A}$ " sites are clearly aligned along faults parallel to the rift wall and most " $\mathrm{B}$ " sites are also elongated, parallel to the faults. Thus, hydrothermal discharges seem to be controlled by deep regional faults. In the southern area where water depth is comprised between $1960 \mathrm{~m}$ to $2025 \mathrm{~m}$, major hydrothermal sites are located inside or at the edge of the small sub-circular depressions caused by dewatering, hydrothermal lithification, and compaction. Thus here, opposite the northern area, discharge on the seafloor is controlled by shallow local structures.

The age of carbon in the hydrocarbons is estimated to be 4200 to 5700 years and the depth of production less than $30 \mathrm{~m}$ (Peter et al., 1991). In addition, in the Guaymas basin, it has been determined that the more volatile and soluble hydrocarbons $\left(<\mathrm{C}_{10}\right)$ are extracted from the source sediments and concentrated at shallow subsurface levels (Kawka and Simoneit, 1994) while the heavy hydrocarbons accumulate deeper in the sediments in the production zone. Even if the depth of oil production is less than $30 \mathrm{~m}$ (Peter et al., 1991), the formation of components of hydrothermal pyrolysates in subsurface sediments may be organized in layers (figure 13 in Kawka and Simoneit, 1994), the light soluble hydrocarbons being extracted from the production zone and accumulated in superficial sediments. Indeed, the type and composition of samples differ from the north to the south of ST (Peter et al., 1991; Simoneit and Lonsdale, 1982; Simoneit et al., 1990). In the north, near the DSDP site, hydrothermal petroleum has a higher content of bitumen while in the south free oil from spire has been extracted. Thus, we may consider that the depressions at the south enhance superficial shallow circulations that preferentially trap and release the volatile and soluble light hydrocarbon into the water column, while the fault controlled vents at the northern fields are connected to "deeper" heavy hydrocarbon sources and extract bitumen found on some hydrothermal spires (Simoneit and Lonsdale, 1982). When cooled in the water column, the light hydrocarbon in the south can form condensates on particles (Kawka and Simoneit, 1994) in the plume. These oil condensates do not mix with seawater and rapidly migrate upward through the water column. With the decreasing ambient pressure, part of the light volatiles can be converted into gas at a determined water depth which depends on their precise composition and proportions. The behaviour of light hydrocarbon condensates and the observed acoustic anomalies are similar: during the liquid phase of condensates escaping from the seafloor, they are acoustically transparent but can generate high backscatter signals with the sudden occurrence of gas bubbles at some water depths, observed here at $\sim 1400 \mathrm{~m}$ below the sea surface.

In contrast, the heavy non-soluble hydrocarbons in the northern area preferentially remain in the sediments and the associated plume, composed only of hydrothermal fluid, is progressively diluted in the water column and only rises to the level of a typical hydrothermal plume, a few hundreds of metres above the seafloor.

\section{Conclusions}

Data acquired from ship and high-resolution AUV surveys of the Guaymas Southern Trough hydrothermal area allow a better understanding of the spatial and temporal evolution of fluid discharges in the area:

- in the southern zone of the study area, major hydrothermal sites are located inside or at the edge of small sub-circular depressions. Some chimneys are cut by superficial scarps at the edge of the depressions while other chimneys seem unaffected by the edge of depressions, suggesting a continuous process with different evolutionary states of chimney development;

- on the sub-bottom profiles, some present-day hydrothermal chimneys appear linked to vertical hydrothermal channels and some reflection layers can indicate buried subsurface areas of more intense hydrothermal compaction and lithification with an estimated age of $\sim 10000$ to 20000 years;

- two types of acoustic anomalies are present in the water column: diffuse and weak echoes detected up to a maximum altitude of $\sim 350 \mathrm{~m}$ above the seafloor, and strong, straight and rootless echoes rising up to $1700 \mathrm{~m}$ above the seafloor. The first ones are related to typical hydrothermal plumes, whereas the strong and rootless echoes, observed only in southern zone, can represent 
discharges of mixed fluids with light non-soluble hydrocarbon condensates;

- the small depressions, present only in the south, probably increase subsurface permeability and favor the release into the water column of light hydrocarbons accumulated in the shallow levels while, in the north, hydrothermal circulation, linked to deeper faults, re-mobilizes heavy hydrocarbons not released into the water column.

Acknowledgements. We thank the entire shipboard cruise participants for their work and support during the BIG cruise. This cruise, funded by IFREMER, obtained a work permit for operating in waters under Mexican jurisdiction (DAPA/2/ 281009/3803, 28 October 2009). The data used in this paper are subject to IFREMER data policy and are available from the French National Oceanographic Data Centre SISMER

https://doi.org/10.17600/10010040.

This work benefited from state funding administered by the French National Research Agency as part of the "Investments for the Future" program, grant no. ANR-10-LabX-19-01.

We thank an anonymous reviewer and the editors for their relevant remarks which have helped us improve the maturity of this manuscript.

Special thanks to Dr. Livio Ruffine for the fruitful discussions we had on the section on oil and condensates.

\section{References}

Aragon-Arreola M, Morandi M, Martin-Barajas A, Delgado-Argote L, Gonzalez-Fernandez A. 2005. Structure of the rift basins in the central Gulf of California: Kinematic implications for oblique rifting. Tectonophysics 409: 19-38. DOI: 10.1016/j. tecto.2005.08.002.

Berndt C, Hensen C, Mortera-Gutierrez C, Sarkar S, Geilert S, Schmidt M, et al. 2016. Rifting under steam-How rift magmatism triggers methane venting from sedimentary basins. The Geological Society of America 44(9): 767-770. DOI: 10.1130/G38049.1.

Campbell AC, Gieskes JM. 1984. Water column anomalies associated with hydrothermal activity in the Guaymas Basin, Gulf of California. Earth and Planetary Science Letters 68(1): 57-72. DOI: 10.1016/0012-821X(84)90140-7.

Canet C, Prol-Ledesma RM, Dando PR, Vasquez-Figueroa V, Shumilin E, Birosta E, et al. 2010. Discovery of massive seafloor gas seepage along the Wagner Fault, northern Gulf of California. Sedimentary Geology 228: 292-303. DOI: 10.1016/j. sedgeo.2010.05.004.

Cherkashov G, Kuznetsov V, Kuksa K, Tabuns E, Maksimov F, Bel'tenev V. 2017. Sulfide geochronology along the Northern Equatorial Mid-Atlantic Ridge. Ore Geology Reviews 87: 147-154. DOI: 10.1016/j.oregeorev.2016.10.015.

Clague DA, Caress DW, Thomas H, Thompson D, Calarco M, Holden $\mathrm{J}$, et al. 2008. Abundance and distribution of hydrothermal chimneys and mounds on the Endeavour Ridge determined by $1-\mathrm{m}$ resolution AUV multibeam mapping surveys. Eos Trans $A G U 89$ (53), Fall Meet. Suppl., Abstract V41B-2079.

Clague DA, Dreyer BM, Paduan JB, Martin JF, Caress DW, Gill JB, et al. 2014. Eruptive and tectonic history of the Endeavour Segment, Juan de Fuca Ridge, based on AUV mapping data and lava flow ages. Geochemistry, Geophysics, Geosystems 5: 33643391. DOI: 10.1002/2014GC005415.
Curray JR, Moore DG, Aguayo JE, Aubry MP, Einsele G, Fornari D, et al. 1982. Guaymas Basin: sites 477, 478 and 481. In: Curray JR, Moore DG, eds. Initial Reports of the Deep Sea Drilling Project 64, Part II. Washington, D.C.: U.S. Govt Printing Office, pp. 211-415.

De Beukelaer SM, MacDonald IR, Guinnasso Jr NL, Murray JA. 2003. Distinct side-scan sonar, RADARSAT SAR, and acoustic profiler signatures of gas and oil seeps on the Gulf of Mexico slope. Geo-Marine Letters 23: 177-186. DOI: 10.1007/ s00367-003-0139-9.

Didyk BM, Simoneit BRT. 1990. Petroleum characteristics of the oil in a Guaymas Basin hydrothermal chimney. Applied Geochemistry 5: 29-40. DOI: 10.1016/0883-2927(90)90033-2.

Dupré S, Scalabrin C, Grall C, Augustin JM, Henry P, Sengör AMC, et al. 2015. Tectonic and sedimentary controls on widespread gas emissions in the Sea of Marmara: Results from systematic, shipborne multibeam echo sounder water column imaging. Journal of Geophysical Research 120. DOI: 10.1002/2014JB011617.

Einsele G, Gieskes JM, Curray J, Moore DM, Aguayo E, Aubry MP, et al. 1980. Intrusion of basaltic sills into highly porous sediments, and resulting hydrothermal activity. Nature 283: 441-445. DOI: $10.1038 / 283441 \mathrm{a} 0$.

Fleischer P, Orsi TH, Richardson MD, Anderson AL. 2001. Distribution of free gas in marine sediments: a global overview. Geo-Marine Letters 21: 103-122. DOI: 10.1007/s003670100072.

Foucher J-P, Dupré S, Scalabrin C, Feseker T, Harmegnies F, Nouze H. 2010. Changes in seabed morphology, mud temperature and free gas venting at the Hakon Mosby mud volcano, offshore northern Norway, over the time period 2003-2006. Geo-Marine Letters 30 (3-4): 157-167. DOI: 10.1007/s00367-010-0193-z.

Galimov EM, Simoneit BRT. 1982. Geochemistry of interstitial gases in sedimentary deposits of the Gulf of California. In: Curray JR, Moore DG, eds. Initial Reports of the Deep Sea Drilling Project 64, Part II. Washington, D.C.: U.S. Govt Printing Office, pp. 781-787. DOI: $10.2973 /$ dsdp.proc.64.124.1982.

Gieskes JM, Kastner M, Einsele G, Kelts H, Niemitz J. 1982. Hydrothermal activity in the Guaymas Basin, Gulf of California: a synthesis. In: Curray JR, Moore DG, eds. Initial Reports of the Deep Sea Drilling Project 64, Part II. Washington, D.C.: U.S. Govt Printing Office, pp. 1159-1167.

Greinert J, Artemov Y, Egorov V, De Batist M, McGinnis D. 2006. $1300-\mathrm{m}$ high rising bubbles from mud volcanoes at $2080 \mathrm{~m}$ in the Black Sea: Hydroacoutic characteristics and temporal variability. Earth and Planetary Science Letters 244(1-2): 1-15. DOI: 10.1016/j.eps1.2006.02.01.

Hay AE. 1984. Remote acoustic imaging of the plume from a submarine spring in an Arctic fjord. Science 225(4667): 1154 1156. DOI: $10.1126 /$ science.225.4667.1154.

Hearn CK, Homola KL, Johnson HP. 2013. Surficial permeability of the axial valley seafloor: Endeavour Segment, Juan de Fuca Ridge. Geochemistry, Geophysics, Geosystems 14(9). DOI: 10.1002/ ggge.20209.

Jamieson JW, Hannington MD, Clague DA, Kelley DS, Delaney JR, Holden JF, et al. 2013. Sulfide geochronology along the Endeavour Segment of the Juan de Fuca Ridge. Geochemistry Geophysics Geosystems 14: 2084-2099. DOI: 10.1002/ggge.20133.

Judd AG, Hovland M, Dimitrov LI, Garcia-Gil S, Jukes V. 2002. The geological methane budget at continental margins and its influence on climate change. Geofluids 2: 109-126. DOI: 10.1016/ S0278-4343(02)00063-8.

Kawagucci S, Ueno Y, Takai K, Toki T, Ito M, Inoue K, et al. 2013. Geochemical origin of hydrothermal fluid methane in sediment associated fields and its relevance to the geographical distribution 
of whole hydrothermal circulation. Chemical Geology 339: 213 225. DOI: 10.1016/j.chemgeo.2012.05.003.

Kawka OE, Simoneit BRT. 1987. Survey of hydrothermallygenerated petroleums from the Guaymas Basin spreading center. Organic Geochemistry 11(4): 311-328. DOI: 10.1016/0146-6380 (87)90042-8.

Kawka OE, Simoneit BRT. 1994. Hydrothermal pyrolysis of organicmatter in Guaymas basin: 1. Comparison of hydrocarbon distributions in subsurface sediments and seabed petroleums. Organic Geochemisitry 22(6): 947-978. DOI: 10.1016/0146-6380 (94)90031-0.

Kluesner J, Lonsdale P, Gonzalez-Fernandez A. 2014. Late Pleistocene cyclicity of sedimentation and spreading-center structure in the Central Gulf of California. Marine Geology 347: 58-68. DOI: 10.1016/j.margeo.2013.11.001.

Lalou C, Reyss JL, Brichet E, Arnold M, Thompson G, Fouquet Y, et al. 1993. New Age Data for Mid-Atlantic Ridge Hydrothermal Sites-Tag and Snakepit Chronology Revisited. Journal of Geophysical Research-Solid Earth 98: 9705-9713. DOI: 10.1029/92JB01898.

Lavelle JW, Di Iorio D, Rona PA. 2013. A turbulent convection model with an observational context for a deep-sea hydrothermal plume in a time-variable cross flow. Journal of Geophysical Research: Oceans 118: 6145-6160. DOI: 10.1002/2013JC009165.

Leblond I, Scalabrin C, Berger L. 2014. Acoustic monitoring of gas emissions from the seafloor. Part I: quantifying the volumetric flow of bubbles. Marine Geophysical Research 35(3): 191-210. DOI: 10.1007/s11001-014-9223-y.

Lizarralde D, Soule SA, Seewald JS, Proskurowski G. 2010. Carbon release by off-axis magmatism in a young sedimented spreading centre. Nature Geoscience 4: 50-54. DOI: 10.1038/ngeo1006.

Lonsdale P, Becker K. 1985. Hydrothermal plumes, hot springs, and conductive heat flow in the Southern Trough of Guaymas Basin. Earth and Planetary Science Letters 73(2-4): 211-225. DOI: 10.1016/0012-821X(85)90070-6.

Lonsdale P, Lawver LA. 1980. Immature plate boundary zones studied with a submersible in the Gulf of California. Geological Society of America Bulletin 91(9): 555-569. DOI: 10.1130/ 0016-7606.

Lonsdale PF, Bischoff JL, Burns VM, Kastner M, Sweeney, RE. 1980. A high-temperature hydrothermal deposit on the seabed at a Gulf of California spreading center. Earth and Planetary Science Letters 49(1): 8-20. DOI: 10.1016/0012-821X(80)90144-2.

MacDonald IR, Leifer I, Sassen TR, Stine P, Mitchell R, Guinass N. 2002. Transfer of hydrocarbons from natural seeps to the water column and atmosphere. Geofluids 2(2): 95-107. DOI: 10.1046/ j.1468-8123.2002.00023.x.

Marchand M, Termonia M, Caprais J-C, Wybauw M. 1994. Purge and trap GC-MS analysis of volatile organic compounds from the Guaymas Basin hydrothermal site (Gulf of California). Analusis 22: 326-331. DOI: A1994PD73100012.

Merewether R, Olsson MS, Lonsdale P. 1985. Acoustically detected hydrocarbon plumes rising from 2-km depths in Guaymas Basin, Gulf of California. Journal of Geophysical Research 90(B4): 3075-3085. DOI: 10.1029/JB090iB04p03075.

Nakamura K, Kawagucci S, Kitada K, Kumagai H, Takai K, Okino K. 2015. Water column imaging with multibeam echo-sounding in the mid-Okinawa Trough: Implications for distribution of deep-sea hydrothermal vent sites and the cause of acoustic water column anomaly. Geochemical Journal 49(6): 579-596. DOI: 10.2343/ geochemj.2.0387.

Nikolovska A, Sahling H, Bohrmann G. 2008. Hydroacoustic methodology for detection, localization, and quantification of gas bubbles rising from the seafloor at gas seeps from the eastern Black Sea. Geochemistry Geophysics Geosystems 9(10). DOI: 10.1029/2008GC002118.

Ondreas H, Cannat M, Fouquet Y, Normand A. 2012. Geological context and vents morphology of the ultramafic-hosted Ashadze hydrothermal areas (Mid-Atlantic Ridge 13 degrees N). Geochemistry Geophysics Geosystems 13. DOI: 10.1029/2012GC004433.

Palmer DR, Rona PA, Mottl MJ. 1986. Acoustic imaging of hightemperature hydrothermal plumes at seafloor spreading centers. Journal of the Acoustical Society of America 80: 888-898. DOI: 10.1121/1.393912.

Peter JM, Simoneit BRT, Kawka OE, Scott SD. 1990. Liquid hydrocarbon-bearing inclusions in modern hydrothermal chimneys and mounds from the southern trough of Guaymas Basin, Gulf of California. Applied Geochemistry 5(1-2): 51-63. DOI: 10.1016/ 0883-2927(90)90035-4.

Peter JM, Peltonen P, Scott SD, Simoneit BRT, Kawka OE. 1991. ${ }^{14} \mathrm{C}$ ages of hydrothermal petroleum and carbonate in Guaymas basin, Gulf of California: Implications for oil generation, expulsion, and migration. Geology 19(3): 253-256. DOI: 10.1130/0091-7613.

Pierre C, Fouquet Y. 2007. Authigenic carbonates from methane seeps of the Congo deep-sea fan. Geo-Marine Letters 27: 249-257. DOI: 10.1007/s00367-007-0081-3.

Rehder G, Leifer I, Brewer PG, Friederich G, Peltzer ET. 2009. Controls on methane bubble dissolution inside and outside the hydrate stability field from open ocean field experiments and numerical modeling. Marine Chemistry 114: 19-30. DOI: 10.1016/ j.marchem.2009.03.004.

Römer M, Sahling H, Pape T, Bohrmann G, Spieß V. 2012. Quantification of gas bubble emissions from submarine hydrocarbon seeps at the Makran continental margin (offshore Pakistan). Journal of Geophysical Research 117: C10015. DOI: 10.1029/ 2011JC007424.

Rona PA, Light R. 2011. Sonar images hydrothermal vents in seafloor observatory. EOS, Transactions, American Geophysical Union 92 (20): 169-170.

Rona PA, Palmer DR, Jones C, Chayes DA, Czarnecki M, Carey EW, et al. 1991. Acoustic imaging of hydrothermal plumes, East Pacific Rise, $21^{\circ} \mathrm{N}, 109^{\circ} \mathrm{W}$. Geophysical Research Letters 18(12): 2233 2236. DOI: 10.1029/91GL02897.

Sakai H, Gamo T, Kim ES, Shitashima K, Yanagisawa F, Tsutsumi M. 1990. Unique chemistry of the hydrothermal solution in the MidOkinawa Trough backarc basin. Geophysical Research Letters 17 (12): 2133-2136. DOI: 10.1029/GL017i012p02133.

Sauter EJ, Muyakshin SI, Charlou JL, Schlüter M, Boetius A, Jerosch $\mathrm{K}$, et al. 2006. Methane discharge from a deep-sea submarine mud volcano into the upper water column by gas hydrate-coated methane bubbles. Earth and Planetary Science Letters 243(3-4): 354-365. DOI: 10.1016/j.eps1.2006.01.041.

Simoneit BRT. 1982. Shipboard organic geochemistry and safety monitoring. In: Curray JR, Moore DG, eds. Initial Reports of the Deep Sea Drilling Project 64, Part II. Washington, D.C.: U.S. Govt Printing Office, pp. 723-728.

Simoneit BRT. 1985. Hydrothermal petroleum: Genesis, migration and deposition in Guaymas Basin, Gulf of California. Canadian Journal of Earth Sciences 22: 1919-1929. DOI: 10.1139/e85-208.

Simoneit BRT, Lonsdale P. 1982. Hydrothermal petroleum in mineralized mounds at the seabed of Guaymas Basin. Nature 295: 198-202. DOI: 10.1038/295198a0.

Simoneit BRT, Kawka OE, Brault M. 1988. Origin of gases and condensates in the Guaymas Basin hydrothermal system (Gulf of California). Chemical Geology 71: 169-182. DOI: 10.1016/ 0009-2541(88)90113-1. 
Simoneit BRT, Lonsdale PF, Edmond JM, Shanks WC. 1990. Deepwater hydrocarbon seeps in Guaymas Basin, Gulf of California. Applied Geochemistry 5(1-2): 41-49. DOI: 10.1016/0883-2927 (90)90034-3.

Simoneit BRT, Goodfellow WD, Franklin JM. 1992. Hydrothermal petroleum at the seafloor and organic matter alteration in sediments of Middle Valley, Northern Juan de Fuca Ridge. Applied Geochemistry 7(3): 257-264. DOI: 10.1016/0883-2927(92) 90041-Z.

Solomon EA, Kastner M, MacDonald IR, Leifer I. 2009. Considerable methane fluxes to the atmosphere from hydrocarbon seeps in the Gulf of Mexico. Nature Geosciences 2: 561-565. DOI: 10.1038/ngeo574.

Speer KG, Rona PA. 1989. A model of Atlantic and Pacific hydrothermal plume. Journal of Geophysical Researches 94(C5): 6213-6220. DOI: 10.1029/JC094iC05p06213.

Svensen H, Planke S, Jamtveit B, Pedersen T. 2003. Seep carbonate formation controlled by hydrothermal vent complexes: a case study from the Vøring Basin, the Norwegian Sea. Geo-Marine Letters 23: 351-358. DOI: 10.1007/s00367-003-0141-2.

Teske A, Hinrichs K, Edgcomb V, De Vera Gomez A, Kysela D, Sylva S.P, et al. 2002. Microbial diversity of hydrothermal sediments in the Guaymas Basin: Evidence for anaerobic methanotrophic communities. Applied and Environmental Microbiology 68(4): 1994-2007. DOI: 10.1128/AEM.68.4.1994-2007.2002.

Teske A, De Beer D, McKay LJ, Tivey MK, Biddle JF, Hoer D, et al. 2016. The Guaymas Basin hiking guide to hydrothermal mounds, chimneys, and microbial mats: Complex seafloor expressions of subsurface hydrothermal circulation. Frontiers in Microbiology 7: 75. DOI: $10.3389 /$ fmicb.2016.00075.

Thal J, Tivey M, Yoerger D, Jöns N, Bach W. 2014. Geologic setting of PACManus hydrothermal area-High resolution mapping and in situ observations. Marine Geology 355: 98-114. DOI: 10.1016/j. margeo.2014.05.011.

Van Andel TH. 1964. Recent marine sediments in the Gulf of California. In: Marine Geology of the Gulf of California. American Association of Petroleum Geologists Memoirs 23: 216-310.

Von Damm KL, Edmond JM, Measures CI, Grant B. 1985. Chemistry of submarine hydrothermal solutions at Guaymas Basin, Gulf of California. Geochimica et Cosmochimica Acta 49(11): 2221-2237. DOI: 10.1016/0016-7037(85)90223-6.

Welhan JA, Lupton JE. 1987. Light hydrocarbon gases in Guaymas Basin hydrothermal fluids - Thermogenic versus abiogenic origin. American Association of Petroleum Geologists 71: 215-223. DOI: A1987G091800006.

Wynn RB, Huvenne VAI, Le Bas TP, Murton BJ, Connelly DP, Bett BJ, et al. 2014. Autonomous Underwater Vehicles (AUVs): Their past, present and future contributions to the advancement of marine geoscience. Marine Geology 352: 451-458. DOI: 10.1016/j. margeo.2014.03.012.

Xu G, Di Iorio D. 2012. Deep sea hydrothermal plumes and their interaction with oscillatory flows. Geochem Geophys Geosyst 13. DOI: 10.1029/2012GC004188.

Xu G, Jackson DR, Bemis KG. 2017. The relative effect of particles and turbulence on acoustic scattering from deep sea hydrothermal vent plumes revisited. Journal of the Acoustical Society of America 141: 1446-1458. DOI: 10.1121/1.4974828.

Yoshikawa S, Okino K, Asada M. 2012. Geomorphological variations at hydrothermal sites in the southern Mariana Trough: Relationship between hydrothermal activity and topographic characteristics. Marine Geology 303: 172-182. DOI: 10.1016/j.margeo.2012.02.013.

Zierenberg RA, Fouquet Y, Miller DJ, Bahr JM, Baker PA, Bjerkgård $\mathrm{T}$, et al. 1998. The deep structure of a sea-floor hydrothermal deposit. Nature 392: 485-488. DOI: 10.1038/33126.

Cite this article as: Ondréas H, Scalabrin C, Fouquet Y, Godfroy A. 2018. Recent high-resolution mapping of Guaymas hydrothermal fields (Southern Trough), BSGF - Earth Sciences Bulletin 189: 6. 